Tarbawy : Jurnal Pendidikan Islam

ISSN : 2407-4462 (Cetak), 2614-5812 (Elektronik)

Vol. 7, No. 2, 2020, Hal. 143-150

DOI: https:// DOI 10.32923/tarbawy.v7i2.1322

\title{
Hakikat Dasar Pendidikan Islam
}

\author{
Dian Fitriana ${ }^{1}$, Hasan Basri ${ }^{2}$, Eri Hadiana ${ }^{3}$ \\ ${ }^{1}$ UIN Sunan Gunung Djati Bandung \\ ${ }^{2}$ UIN Sunan Gunung Djati Bandung \\ ${ }^{3}$ UIN Sunan Gunung Djati Bandung
}

\section{Info Artikel :}

Diterima 13 Oktober 2020

Direvisi 21 Oktober 2020

Dipublikasikan 26 Oktober 2020

\section{Kata Kunci:}

Pendidikan

Dasar Pendidikan Islam

Hakikat Pendidikan Islam

Keyword:

Education

Basic Islamic Education

The Nature of Islamic Education

\begin{abstract}
ABSTRAK
Tulisan ini membahas tentang hakikat dasar pendidikan Islam. Metode penelitian ini menggunakan literature research atau penelitian kepustakaan yang akan dianalisis dan disimpulkan. Dalam pengumpulan data penulis menggunakan studi pustaka yaitu penelitian yang dilakukan dengan cara menggunakan data-data yang berkaitan dengan dasar-dasar pendidikan Islam dari buku-buku, jurnal, koran, internet dan sumber lainnya yang relevan. Penelitian ini bersifat kualitatif yang lebih mengutamakan penggalian, penemuan, pembacaan, penjelasan dan penyampaian makna atau simbol data yang tersurat dan terserat dari data yang dikumpulkan. Hasil penelitian ini berupa: 1) Pengertian Pendidikan Islam, 2) Dasar pendidikan Islam, 3) Fungsi pendidikan dalam Islam, 4) Tujuan Pendidikan dalam Islam, 5) Hubungan antara Tujuan Hidup dengan Tujuan Pendidikan dalam Islam. Kesimpulan dari tulisan ini bahwa pendidikan Islam bertujuan untuk menjadikannya selaras dengan tujuan utama manusia menurut Islam, yakni beribadah kepada Allah SWT. Pendidikan Islam harus dibangun di atas konsep kesatuan (integrasi) antara pendidikan aqliyah dan qalbiyah, sehingga menghasilkan manusia muslim yang pintar secara intelektual sekaligus terpuji secara moral.
\end{abstract}

\begin{abstract}
ABSTRAK
This paper discusses the basic nature of Islamic education. This research method uses literature research or literature research that will be analyzed and concluded. In collecting data the author uses literature studies, namely research conducted by using data relating to the basics of Islamic education from books, journals, newspapers, internet and other relevant sources. This research is qualitative in nature which prioritizes excavation, discovery, reading, explanation and conveying the meaning or symbol of data which is explicit and entangled from the data collected. The results of this study include: 1) Definition of Islamic Education, 2) Basic Islamic education, 3) The function of education in Islam, 4) The Purpose of Education in Islam, 5) The Relationship between the Purpose of Life with the Purpose of Education in Islam. The conclusion of this paper is that Islamic education aims to make it in harmony with the main goal of humans according to Islam, namely worship of Allah SWT. Islamic education must be built on the concept of unity (integration) between aqliyah and qalbiyah education, so as to produce Muslims who are intellectually smart and morally praiseworthy.
\end{abstract}

\section{Koresponden:}

Dian Fitriana,

Email: dianfitriana2608@gmail.com

\section{Pendahuluan}

Pendidikan merupakan bagian yang tidak bisa dipisahkan dengan kehidupan manusia. Karena pendidikan sealau menjadi pembincangan hangat di tengah-tengah masyarakat sekalipun ia tidak mengerti pendidikan, bahkan dimanapun dan kapanpun pendidikan selalu dibicarakan bahkan diperdeabatkan sekalipun. Begitupun di negara yang paling maju sekalipun, pendidikan pasti menjadi isu yang sangat krusial dan pasti ada sebagian kalagan yang mengkritik. Hal ini menunjukkan bahwa pembicaraan tentang pendidikan tidak akan berhenti selagi masih ada kehidupan dimuka bumi ini. 
Dalam pemabangunan bangsa, sektor utama yang mendapat prioritas adalah pendidikan yang aksentuasinya adalah pada peningkatakan keimanan dan ketakwaan kepada Tuhan yang Maha Esa, serta akhlak mulia, sebagaimana dirumuskan dalam tujuan pendidikan nasional (UU Nomor 20 Tahun 2003). "Pendidikan Nasional bertujuan untuk mengembangkan potensi peserta didik agar menjadi manusia yang beriman dan bertakwa kepada Tuhan Yang Maha Esa, berakhlak mulia, sehat, berilmu, cakap, kreatif, mandiri, dan menjadi warga negara yang demokratis serta bertanggung jawab" (Undang-Undang Nomor 20 Tahun 2003 tentang Sistem Pendidikan Nasional).

Adapun tantangan pendidikan Islam, seiring diberlakukannya undang-undang tersebut menurut Mastuhu adalah: Pertama, mampukah sistem Pendidikan Islam Indonesia menjadi center of excellence bagi perkembangan iptek yang tidak bebas nilai, yaitu mengembangakn Iptek dengan sumber ajaran A1Quran dan Sunnah? Kedua, mampukah sistem Pendidikan Islam Indonesia menjadi pusat pembeharuan pemikiran Islam yang benar-benar mampu merespons tantangan zaman, tanpa mengabaikan aspek dogmatis yang wajib diikuti? Ketiga, mampukah ahli-ahli Pendidikan Islam menumbuhkembangkan kepribadian termasuk Pendidikan Karakter Bangsa yang benar-benar beriman dan bertakwa kepada Allah SWT lengkap dengan kemampuan bernalar ilmiah yang tidak mengenal batas akhir? (Mastuhu, 1999).

Untuk mengadapi tantangan-tantangan di atas sekaligus mencari solusi terbaik dalam menghidupkan dan mengembangkan serta memberdayakan sistem pendidikan Islam, baik secara proses maupun sebagai lembaga menurut Mastuhu, diperlukan konsep-konsep baru yang strategis, sehingga pada gilirannya dapat dikembangkan menjadi teori-teori yang teruji dan dapat dioperasionalkan di lapangan. Upaya mencari paradigma baru, selain harus mampu membuat konsep yang mengandung nilai-nilai dasar strategis, proaktif, dan antisipatif terhadap perkembangan di masa mendatang, juga harus mampu mempertahankan nilai-nilai dasar yang benar dan diyakini untuk terus dipelihara dan dikembangkan, apalagi dalam kehidupan modern dan dunia global sekarang ini (Mastuhu, 1999).

Dengan demikian, maka Pendidikan Islam akan berfungsi dengan baik bagi upaya pemberdayaan dan pengembangan potensi-potensi yang dibawa manusia dengan sistem pendidikan yang bersendikan nilainilai Islami yang lebih efektif, efesien, dan produktif.

Penelitian ini bersifat kualitatif yang lebih mengutamakan penggalian, penemuan, pembacaan, penjelasan dan penyampaian makna atau simbol data yang tersurat dan terserat dari data yang dikumpulkan Penelitian ini adalah jenis penelitian kepustakaan. Mestika Zed menyebutkan bahwa penelitian kepustakaan adalah penelitian yang dilakukan dengan membaca karya-karya yang terkait dengan persoalan yang akan dikaji dan mencatat bagian penting yang ada hubungannya dengan topik bahasan. Moh. Nazir menjelaskan pula bahwa penelitian kepustakaan (library research) adalah suatu metode yang dipakai dengan penala'ahan buku-buku yang berhubungan dengan tema yang dibahas ( $M$. Nazir, 2005).

Dalam pengumpulan data penulis menggunakan studi pustaka yaitu penelitian yang dilakukan dengan cara menggunakan data-data yang berkaitan dengan dasar-dasar pendidikan Islam dari buku-buku, jurnal, koran, internet dan sumber lainnya yang relevan.

\section{Pembahasan}

\section{Pengertian Pendidikan Islam}

Pendidikan adalah usaha sadar dan terencana untuk mewujudkan suasana belajar dan proses pembelajaran agar peserta didik secara aktif mengembangkan potensi dirinya untuk memiliki kekuatan spiritual keagamaan, pengendalian diri, kepribadian, kecerdsan, akhlak mulia, serta ketrampilan yang diperlukan dirinya, masyarakat, bangsa dan Negara (Undang-Undang Republik Indonesia No. 20 Tahun 2003 tentang Sistem Pendidikan Nasional).

Pendidikan diartikan sebagai proses timbal balik dari tiap pribadi manuisa dalam penyesuaian dirinya dengan alam, dengan teman, dan dengan alam semesta. Pendidikan merupakan pula perkembangan yang terorganisasi dan kelengkapan dari semua potensi-potensi manusia; moral, intelektual dan jasmani (fisik), oleh dan untuk kepribadian individunya dan kegunaan masyarakatnya yang diharapkan demi menghimpun semua aktivitas tersebut bagi tujuan hidupnya (tujuan akhir) (Sidik, 2016). 
Sementara Pendidikan Islam menurut Yusuf Qardawi berpendapat, pendidikan Islam adalah Pendidikan manusia seutuhnya; akal dan hatinya, jasmani dan rohaninya, akhlak dan ketrampilannya (Yusuf qardawi, 1980). Sedangkan menurut Hasan Langgulung, pendidikan Islam adalah Suatu proses penyiapan generasi muda untuk mengisi peranan, memindahkan pengetahuan dan nilai-nilai Islam yang diselaraskan dengan fungsi manusia untuk beramal di dunia dan memetik hasilnya di akhirat. Lebih lanjut ia menjelaskan bahwa pendidikan Islam dalam pengertian di atas merupakan suatu proses pembentukan individu berdasarkan ajaran Islam yang diwahyukan Allah kepada Muhammad melalui proses mana individu dibentuk agar dapat mencapai derajat yang tinggi, sehingga mampu menunaikan tugasnya sebagai kholifah di bumi yang dalam kerangka lebih lanjut mewujudkan kebahagiaan di dunia dan akhirat.16Pendidikan sebagai usaha membina dan mengembangkan peribadi manusia dari aspek-aspek rohaniah dan jasmaniah juga harus berlangsung secara bertahap (Hasan Langgulung, 1980).

Secara umum pendidikan Islam dapat didefinisikan sebagai suatu proses atau usaha yang dilakukan secara sadar untuk membina, mengarahkan dan mengembangkan secara optimal fitrah atau potensi manusia dalam segenap aspek, baik jasmani maupun rohani berdasarkan nilai-nilai ajaran Islam untuk memperoleh kebahagiaan hidup di dunia dan akhirat dengan memerankan fungsinya sebagai Abdullah dan Khalifatullah (Sidik, 2016).

Oleh karena suatu kematangan yang bertitik akhir pada optimalisasi perkembangan/pertumbuhan, baru dapat tercapai bilamana berlangsung melalui peroses demi peroses kearah tujuan akhir perkembangan atau pertumbuhannya (M. Arifin, 1993).

Sejalan dengan perkembangan zaman dan tuntutan kebutuhan manusia yang semakin bertambah dan luas, maka pendidikan Islam bersifat terbuka dan akomodatif terhadap tuntutan zaman sesuai norma-norma Islam. Dalam studi pendidikan, sebutan " pendidikan Islam” pada umumnya dipahami sebagai suatu ciri khas, yaitu jenis pendidikan yang berlatar belakang keagamaan. Dapat juga di ilustrasikan bahwa pendidikan yang mampu membentuk "manusia yang unggul secara intelektual, kaya dalam amal, dan anggun dalam moral". Menurut cita-citanya pendidikan Islam memproyeksi diri untuk memperoleh "insan kamil", yaitu manusia yang sempurna dalam segala hal, sekalipun di yakini baru hanya Nabi Muhammad SAW yang telah mencapai kualitasnya (Muslim, 1997). Lapangan pendidikan Islam diidentik dengan ruang lingkup pendidikan Islam yaitu bukan sekedar peroses pengajaran (face to face), tapi mencakup segala usaha penanaman (internalisasi) nilai-nilai Islam kedalam diri subyek didik (Nasir Budiman, 2001).

\section{Dasar Pendidikan Islam}

Yang dimaksud dengan dasar pendidikan Islam adalah wawasan tajam terhadap sistem hidup Islam yang sesuai dengan kedua sumber pokok (Quran dan Sunnah), yang menjadi dasar bagi perumusan tujuan dan pelaksanaan Pendidikan Islam. Menurut Abidin Ibnu Ruslan, ada beberapa nilai fundamental dalam sumber pokok ajaran Islam yang harus dijadikan dasar bagi pendidikan Islam (Abidin, 1998), yaitu:
a. Aqidah
b. Akhlak
c. Penghargaan kepada akal
d. Kemanusiaan
e. Keseimbangan
f. Rahmat bagi seluruh alam (Rahmatan lil'alamin).

Ini artinya, bahwa pendidikan Islam dalam perencanaan, perumusan, dan pelaksanaannya pada pembentukan pribadi yang berakidah Islam, berakhlak mulia, berpikiran bebas, untuk mengarahkan dan mengembangkan potensi manusia secara terpadu tanpa ada pemisahan. Seperti aspek jasmani dan rohani, akal dan hati, individu dan sosial, duniawiah dan ukhrawiah, dan seterusnya. Karena pendidikan Iskam mengarah pada pembentkan insan paripurna (insan kamil), yakni yang dapat menjadi rahmatan lil'alamin, mampu memerankan fungsinya sebagai Abdullah dan kholifatullah (Abidin, 1998).

Dasar pendidikan Islam dapa dibagi dalam tiga kategori yaitu:

a. Dasar Pokok 
Nabi Muhammad SAW sebagai pendidik pertama pada masa awal pertumbuhan awal Islam telah menjadikan Al-Qur'an sebagai dasar pendidikan Islam disamping sunnah beliau sendiri (Ramayulis, 2011).

Kedudukan Al-Qur'an dan sunnah sebagai sumber pokok dapat dipahami dari ayat AlQur'an sendiri.

Firman Allah:

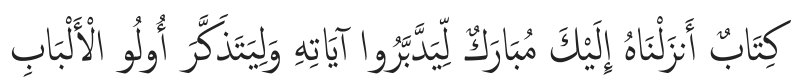

Artinya: "Ini adalah sebuah Kitab yang kami turunkan kepadamu penuh dengan berkah supaya mereka memperhatikan ayat-ayatNya dan supaya mendapat pelajaran orang-orang yang mempunyai fikiran." (QS. Shaad: 29)

Dan firman Allah:

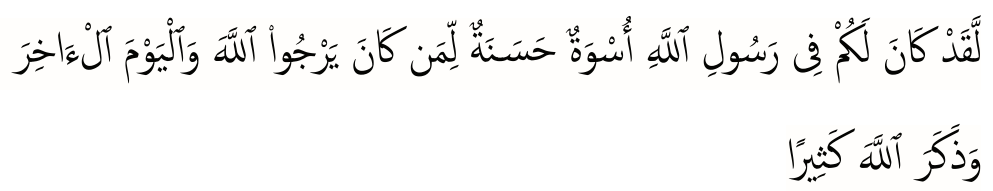

Artinya: "Sesungguhnya Telah ada pada (diri) Rasulullah itu suri teladan yang baik bagimu (yaitu) bagi orang yang mengharap (rahmat) Allah dan (kedatangan) hari kiamat dan dia banyak menyebut Allah." (QS. Al-Ahzab: 21)

b. Dasar Tambahan

Pada masa khulafaurrasyidin sumber pendidikan Islam sudah muali mengalami perkembangan. Selain Al-Qur'an dan sunnah juga perkataan, sikap dan perbuatan para sahabat.

Usaha-usaha para sahabat dalam pendidikan Islam sangat menentukan bagi perkembangan pendidikan Islam ampai sekarang, di antaranya:

1. Abu Bakar melakukan kodifikasi Al-Qur'an;

2. Umar bi Khattab sebagai bapak reaktuator terhadap ajaran Islam yang dapat dijadikan prinsip strategi pendidikan;

3. Usman bin Affan sebagai bapak pemersatu sistematika penulisan Al-Qur'an;

4. Ali bin Abi Thalib sebagai perumus konsep-konsep pendidikan (Ramayulis, 2011 ).

c. Dasar Operasional

Dasar operasional pendidikan Islam adalah dasar yang terbentuk sebagai aktualisasi dari dasar ideal. Menurut Hasan Langgulung, dasar operasional ada enam macam (Ramayulis, 2011), yaitu:

1) Dasar Historis

Dasar historis adalah dasar yang memberikan andil kepada pendidikan dari hasil pengalaman masa lalu berupa peraturan dan budaya masyarakat. Sistem pendidikan tidaklah muncul begitu saja tetapi ia merupakan mata rantai yang berkelanjutan dari cita-cita dan praktek pendidikan di maa lampau yang tersurat mau pun yang tersirat.

2) Dasar Sosial

Dasar soial yaitu dasar yang memberikan kerangka budaya dimana pendidikan itu berkembang, seperti memindahkan, memilih dan mengembangkan kebudayaan. Dimana pendidikan bertolak atau bergerak dari kerangka kebudayaan yang ada baik memindahkan, memilih dan mengembangkan kebudayaan itu sendiri.

3) Dasar Ekonomi

Yaitu dasar yang memberikan persfektif terhadap potensi manusia berupa materi dan persiapan yang mengatur sumber-sumbernya yang bertanggung jawab terhadap anggaran perbelanjaannya. Pada setiap kebijakan pendidikan haruslah mempertimbangkan faktor ekonomis karena kondisi sosial masyarakat yang beraneka ragam akan dapat menjadi hambatan berlangsungnya pendidikan. Untuk itu, setiap kebijakan-kebijakan pendidikan harus mempetimbangkan faktor ekonomis.

4) Dasar Politik 
Yaitu dasar yang memberi bingkai dan ideologi daar yang digunakan sebagai tempat bertolak untuk mencapai tujuan yang dicita-citakan dan rencana yang telah dibuat. Dalam mencapai tujuan pendidikan yang telah direncanakan harus bertitik tolak dari ideologi yang di anut karena hal ini merupakan dasar operasional pendidikan.

5) Dasar Psikologis

Yaitu dasar yang memberi informasi tentang watak pelajar-pelajar, guru-guru, cara-cara terbaik dalam praktek, pencapaian dan penilaian dan pengukuran serta bimbingan. Keberhasilan pendidikan dalam mencapai tujuan, harus memiliki informasi tentang watak peserta didik, pendidik, pengukuran dan penilaian yang terbaik.

6) Dasar Fisiologis

Yaitu dasar yang memberi kemampuan memilih yang terbaik, memberi arah suatu sistem, mengontrol dan memberi arah kepada semua dasar-dasar operasional lainnya. Dasar fisiologis adalah dalam rangka menentukan arah, mengontrol serta memilih yang terbaik dari dasar-dasar operasional untuk dilaksanakan.

\section{Fungsi Pendidikan dalam Islam}

Pada hakikatnya, pendidikan adalah suatu peroses berlangsung secara kontinu dan berkesinambungan. Maka tugas dan fungsi pendidkan yang perlu diemban oleh pendidikan Islam merupakan peroses tampa akhir sejalan dengan konsensus universal yang diterapkan oleh Allah SWT dan Rasul-Nya, dengan istilah life long education (Q.S. Al-Hijr: 99) atau istilah Noeng Muhajir, belajar tiada akhir (no limits of study). Konsep ini bermakna bahwa tugas dan funsi pendidikan memilik sasaran pada peserta didik yang senantiasa tumbuh dan berkembang secara dinamis, mulai kandungan sampai akhir hayatnya (Mukodi, 2010).

Dengan demikian dapat, dipahami bahwa fungsi pendidikan Islam tidak saja dalam rangka membina manusia beriman dan bertakwa, berketerampilan dan berbudaya, tetapi manusia yang mampu mengatasi berbagai maslah dalam kehidupan, kemasyarakatan dan kemanusiaan, sehingga ia mampu memposisikan dirinya menjadi manusia yang berkualitas bagi agama, masyarakat dan bangsanya (Abd. Rahman, 2002).

Menurut Yusuf Amir Faisal, bahwa pendidikan islam dengan bertitik tolak dari prinsip Iman-islamihsan atau akidah-ibadah-akhlak untuk menuju satu sasaran kemuliaan manusia dan budaya yang diridhai oleh Allah SWT, setidak-tidaknya memiliki fungsi-fungsi (Abd. Rahman, 2002) sebagai berikut :

a) Individualisasi nilai dan ajaran Islam demi terbentuknya derajat manusia yang muttaqimdalam bersikap, berpikir dan berperilaku.

b) Sosialisasi nilai-nilai dan ajaran Islam demi terbenruknya umat Islam.

c) Rekayasa kultur umat Islam demi terbentuk dan berkembangnya peradaban Islam.

d) Menemukan, mengembangkan, serta memelihara ilmu, tekhnologi, keterampilan demi terbentuknya para manjer dan manusia profesional.

e) Pengembangan intelektual muslim yang mampu mencari, mengembangkan serta memelihara ilmu dan tekhnologi.

f) Pengembangan pendidikan yang berkelanjutan dalam bidan ekonomi, fisika, kimia, seni musik, seni budaya, politik, olah raga, kesehatan, d1

g) Pemgembangan kualitas muslim dan warga negara sebagai anggota dan pembina masyarakat yang berkualitas kompetitif.

Bila dilihat secara operasional, fungsi pendidikan dapat dilihat dari dua bentuk, yaitu :

a. Alat untuk memelihara, memperluas, dan menghubungkan tingkat kebudayaan, nilai-nilai tradisi dan sosial,serta ide-ide masyarakat dan nasional. 
b. Alat untuk mengadakan perubahan, inovasi dan perkembangan. Pada garis besarnya, upaya ini dilakukan melalui potensi ilmu pengetahuan dan skill yang dimiliki, serta melatih tenaga manusia (peserta didik) yang produktif dalam menemukan perimbangan perubahan sosialekonomi yang demikian dinamis.

\section{Tujuan Pendidikan dalam Islam}

Sebagai aktivitas yang bergerak dalam proses pembinaan kepribadian muslim, maka pendidikan Islam memerlukan asas atau dasar yang dijadikan landasan kerja. Dengan dasar ini akan memeberikan arah bagi pelaksanaan pendidikan yang telah diprogramkan. Dalam konteks ini, dasar yang menjadi acuan pendidikan Islam hendaknya merupakan sumber nilai kebenaran dan kekuatan yang menghantarkan peserta didik kearah pencapaian pendidikan. Oleh karena itu, dasar yang terpenting dari pendidikan Islam adalah Al-Qur'an dan Hadist (Sunnah Rasulullah).

Dalam pendidikan Islam, Sunah Rasul mempunyai dua fungsi, yaitu :

a. Menjelaskan system pendidikan Islam yang terdapat dalam Al-Qur'an dan menjelaskan hal-hal yang tidak terdapat didalamnya.

b. Menyimpulkan metode pendidikan dari kehidupan Rasullullah bersama sahabat.

Secara lebih luas, dasar pendidikan Islam terdiri dari 6 macam, yaitu; Al-Qur'an, Sunnah, Qaul alshahabat, masail al mursalah, 'urf, dan pemikiran hasil ijtihad intelektual Islam. yaitu:

Dalam perumusan tujuan pendidikan Islam, paling tidak ada beberapa hal yang perlu diperhatikan

a. Tujuan dan tugas manusia di muka bumi, baik secara vertical maupun horizontal.

b. Sifat-sifat dasar manusia.

c. Tuntutan masyarakat dan dinamika peradaban kemanusiaan.

Dimensi-dimensi kehidupan ideal Islam

Dalam aspek ini, ada 3 macam dimensi ideal Islam, yaitu ;

a. Mengandung nilai yang berupaya meningkatkan kesejahteraan hidup manusia dibumi.

b. Mengandung nilai yang mendorong manusia berusaha keras untuk meraih kehidupan yang baik.

c. Mengandung nilai yang dapat memadukan antara kepentingan kehidupan dunia dan akhirat.

Menurut Hasan Langgulung, berbicara tentang tujuan pendidikan Islam tidak dapat tidak mengajak kita berbicara tentang tujua hidup. Sebab tujuan pendidikan bertujuan untuk memelihara kehidupan manusia. Tujuan hidup ini menurutnya tercermin dalam Q.S. Al-An'am ayat 162 yang artinya: "Sesungguhnya sholatku, ibadahku, hidupku dan matiku hanyalah untuk Allah. Ini berarti bahwa tujuan Pendidikan Islam juga selaras dengan tujuan hidup yaitu untuk mengabdi kepada Allah" (Hasan Langgulung, 1980).

Sejalan dengan pendapat Hasan Langgulung, M. Natsir mengatakan, bahwa perhambaan kepada Allah yang menjadi tujuan hidup dan tujuan pendidikan bukanlah suatu perhambaan yang memberikan keuntungan kepada obyek yang disembah, tapi perhambaan yang mendatangkan kebahagiaan bagi yang menyembah, perhambaan yang memberikan kekuatan bagi yang merperhambakan dirinya. Selanjutnya, ia mengatakan bahwa akan menjadi orang yang memperhambakan seluruh jasmani dan rohaninya kepada Tuhan, untuk kemenangan dirinya dengan arti yang seluas-luasnya yang dapat dicapai oleh manusia. Itulah tujuan hidup manusia di atas dunia dan itu pulalah yang seharusnya menjadi tujuan bagi proses pendidikan (M. Natsir, 1959).

\section{Hubungan antara Tujuan Hidup dengan Tujuan Pendidikan dalam Islam}

Pada dasarnya tujuan pendidikan merupakan kristalisasi nilai-nilai yang di maksud nilai-nilai ialah daya pendorong dalam hidup, yang memberi makna dan pengabsahan pada tindakan seseorang (Hery Noer Aly, 1999). 
Tujuan pendidikan ditentukan oleh pendidik sebagai orang yang mengarahkan proses pendidikan. Karenanya tujuan pendidikan berkaitan erat dengan nilai-nilai yang di junjung tinggi oleh pendidik di dalam hidupnya. Dengan perkataan lain, tujuan pendidikan tidak bisa di pisahkan dari tujuan hidup pendidik. Tujuan pendidikan Islam sama dengan tujuan hidup yang di tetapkan oleh Allah. Di dalam al-Qur'an Allah telah memberitahukan tujuan diadakannya atau dihidupkannya manusia atau tujuan hidup manusia:

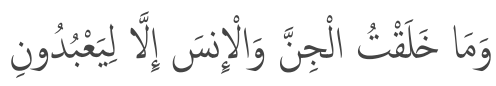

Artinya: "Dan Aku tidak menciptakan jin dan manusia melainkan supaya mereka mengabdi kepada-Ku."(Q.S. adz-Dzariyat, ayat 56)

Dengan demikian tujuan hidup manusia adalah untuk menjadi pengabdi Allah, menjadi pelayan Allah, penurut kemauan Allah. Orang yang menurut kemauan Allah itu dinamakan juga taqwa. Orang yang paling tinggi derajat nilai dirinya dan paling mulia di sisi Allah adalah orang yang paling bertakwa (Akmal Hawi, 2005).

Pendidikan Islam bukan hanya pengajaran teoritis, melainkan juga benar-benar melakukan pembentukan kecakapan riil yang diperlukan bagi seorang pengabdi Allah yang mendapat tugas sebagai khalifa di bumi, pengabdi Allah dinamakan juga orang takwa itubukanlah ahli teori keagamaan, melainkan tahu dengan jelas dan lengkap seluruh isi ajaran Allah di dalam Al-Qur'an dan cakap mengerjakannya dalam praktek hidup sehari-hari, baik selaku individu maupun selaku keluarga, warga masyarakat dan bangsa (Akmal Hawi, 2005).

\section{Kesimpulan}

Manusia dengan kemampuan akal dan hatinya menyandang predikat sebagai makhluk pemikir sekaligus perasa. Nilai Pendidikan Islam terletak pada keseimbangan antara aspek pemikiran dan perasaan atau antara aspek pikir dan dzikir. Pendidikan Islam adalah proses pembentukan kepribadian manusia kepribadian Islam yang luhur. Bahwa pendidikan Islam bertujuan untuk menjadikannya selaras dengan tujuan utama manusia menurut Islam, yakni beribadah kepada Allah SWT.

Maka berdasarkan cara pandang di atas, Pendidikan Islam harus dibangun di atas konsep kesatuan (integrasi) antara pendidikan aqliyah dan qalbiyah, sehingga menghasilkan manusia muslim yang pintar secara intelektual sekaligus terpuji secara moral.

Diharapkan dengan pemahaman hakikat pendidikan Islam ini, memberi motivasi agar manusia khususnya muslim selalu mencari ilmu hingga akhir hayat, dalam rangka merealisasikan tujuan yang telah disebutkan dalam QS. Adz-Dzariyat: 56 dapat diaplikasikan secara berkelanjutan.

\section{Referensi}

Al-Qur'an dan Terjemahnya. 2015. Departemen Agama RI. Bandung: CV Darus-Sunnah

Abdullah, Abd. Rahman. 2010. Aktualisasi konsep dasar Pendidikan Islam (rekonsstruksi pemikiran tinjauan filsafat pendidikan Islam), Yogyakarta: UII Press.

Abidin Ibn Rusn. 1998. Pemikiran Al-Ghazali Tentang Pendidikan. Yogyakarta: Pustaka Pelajar. Aly, Hery Noer. 1999. Ilmu Pendidikan Islam, Jakarta: Logos Wacana Ilmu.

Arifin, M. 1993. Filsafat Pendidikan Islam, Cet. III. Jakarta: Bumi Aksara.

Budiman, Nasir. Pendidikan dalam Persepektif Al-Qur'an, Cet.I. Jakarta: Madani Press.

Hawi, Akmal. 2005. Dasar-dasar Pendidikan Islam, Palembang : IAIN Raden Fatah Press.

Langgulung, Hasan. 1980.Beberapa Pemikiran Tentang Pendidikan Islam. Bandung: Al-Ma'arif, Mastuhu. 1999. Memberdayakan Sistem Pendidikan Islam, Jakarta: Logos Wacana Ilmu.

Mestika, Zed. 2008. Metode Penelitian Kepustakaan, Jakarta: Yayasan Obor Indonesia.

M. Natsir. 1959. Capita Selecta. Jakarta: W. Van Hoove.

Nazir, M. 2005. Metode Penelitian. Bogor: Ghalia Indonesia 
Mukodi. 2010. Pendidikan Islam Terpadu, reformasi pendidikan di era gelobal. Yogyakarta : Magnum Pustaka. Muslim dan Wijdan, Aden. 1997. Pemikiran Islam dalam Peradaban Industrial. Yogyakarta: Aditya Media Qardawi, Yusuf. 1980. Pendidikan Islam dan Madrasah Hasan Al-Banna Terj. Jakarta: Bulan Bintang. Ramayulis. 2011. Ilmu Pendidikan Islam (Edisi Revisi). Jakarta: Kalam Mulia.

Sidik, hasbi. Hakikat Pendidikan Islam. Arriwayah: Jurnal kependidikan, Vo. 8, No. 1 (2016). http://e-jurnal.stainsorong.ac.id/index.php/Al-Riwayah/article/view/109

Undang-Undang Nomor 20 Tahun 2003 tentang Sistem Pendidikan Nasional, Bab III, Pasal 3. Bandung: Fokus Media.

Undang-Undang Republik Indonesia No. 20 Tahun 2003 tentang Sistem Pendidikan Nasional Bab I Pasal 1 Ayat 1 